\title{
The Implementation Model of Poor Fisher Community Empowerment A Study of Poor Fisher Families in Pangkep, Indonesia
}

\author{
Anwar Parawangi \\ University of Muhammadiyah Makassar \\ Makassar, Indonesia \\ ambae58@yahoo.com
}

\author{
Rulinawaty Kasmad \\ University of Muhammadiyah Makassar \\ Makassar, Indonesia \\ rulinawaty@yahoo.co.id
}

\begin{abstract}
This study aims to figure out a model to implement the empowerment in poor fisher: (1) the tendency of local rural development has not improved the existent capability and solid society in coastal community poor fisher family. (2) There are many programs that have been done but none can solve the obstacles. (3) The development model and the existent capability were taken in the matter of helplessness, orientation achievement, weak collection response, lack of vision, and a low stimulus of change. The method used in this research is a qualitative approached with case study as the research strategy. The result of this research shows that the activities empowerment of poor fisher community has not achieved, although the programs are aspirated, democratic, and well-coordinated. This related to the capability of organization and inter-organization behavior. Similarly, the lower-level bureaucracy performed no discretion. Furthermore, the target group affected the success of the program, approved or disapproved.
\end{abstract}

Keyword: program implementation; fisher community; empowerment; Mattiro Bombang; Pangkep

\section{INTRODUCTION}

Fishermen is one of community member that has the lowest level of welfare. In other words, the fisher people are the poorest in subsystem community [1]. The poor fishers in Indonesia are dealt with many obstacles that already analyzed in various writings and researches. One of them is written by Mubyarto [2], his study evaluates the economic growth of poor fisher community in Jepara. According to Mubyarto et al, the poor fisher poverty is caused by structure oppression. The fishermen is divided into rich and very rich group. On the other hand, poor and very poor group. The research shows an exploitation of rich fishermen to poor fishermen. The same problems also resembled to fishermen in Riau Islands. As said by Mubyarto and Sutrisno [3], the poverty of fishermen in that regions is mostly caused by structure oppression, the rich fishermen has ruled the poor fishermen. The result indicates that the poor fisher has no power in socio-economic and politic conditions in each region. To figure out the poverty of coastal community, in particular poor fisher, programs of poverty are coordinated directly by technical agencies, from central to regional. Hence, the government had a definite standard to reduce the rate of poverty from $11,5 \%$ to $12,5 \%$ and the employment rate is 400.000 pro $1 \%$ of economic growth.

The government in New Order era to Reformation era was involved to inspect this issue but still not given decent outcome. The poverty still exists in fisher community, quality and quantity aspects. It is clearly shows the policy is not carry out well by the implementer and this grow into a formidable challenge to interpreting the prevalent policies. The relation between organization and interorganization indicates that the public policy is rarely implemented in the groups itself, moreover there is no well-coordinated organizational tools [4][5] The missions of the implementation for this policy have to transform the general policy to a crystal clear rules. This relationship and arrangement within organizations is essential, either public organization or non-public organization, due to limited human resources in public service area.

Therefore, this research is focused to the model implementation of poor fisher empowerment. Accordingly, Winter [4] composed important variables as a key factor that can be used to organized the empowerment community programs in poverty alleviation. This is called Integrated Implementation Model. As Winter [4] said, one of the variables in the implementation of policy is the behavior of organization and interorganizational function. The improvement of policy implementation is eminently based on organizational resources, which engaged to the ability of building interrelated link networks. Similarly, to low level bureaucratic behavior, it prioritized the community relation to emphasize the policy. This low level bureaucratic behavior act as essential role in implementation public policy, its performance should be consistently related to standard program activities. [6] Additionally, the target group behavior act as receiver that roles the policy impact and give influence to the performance of program implementation action.[4] This action could be endorsing or rejecting. [7]

\section{RESEARCH METHOD}

The object of this research is poor fisher family and the community, where the information is gathered. The research was conducted in Mattiro Bombang, Sub-district of Liukang Tupabbiring, North Pangkep Regency.

Qualitative method is used in this research, because the problems happened between the organization and interorganization in empowerment program of the poor fisher community are often found within the process, so it is qualitatively relevant.

The research strategy is used to solve the problem and achieve the research objectives that already determined in case

Corresponding author: Rulinawati Kasmad 
study. [8], that "an inquiry empiric investigates real-life context phenomena".

\section{RESULT AND DISCUSSION}

\section{A. Overview of Research Area}

Pangkajene Kepulauan Regency (Pangkep) is a regency area in South Sulawesi Province, located in the north of Makassar City. This range will be partitioned under three parts in particular coastal, highland, and the archipelago. The archipelago region of Pangkep Regency consists of 112 islands, and 22 of them are uninhabited. Pangkajene and Kepulauan Regency consists of 13 sub-districts. The number of residents in Pangkep regency amounted to 334,046 people. The village of Mattiro Bombang is one of the villages in Liukang Tupabbiring Sub-district that consists of four inhabited islands; Salemo Island, Sagara Island, Sabangko Island, and Sakuala Island, and a few reefs. Meanwhile, the number of poor households in the village of Mattiro Bombang is higher than in other villages. Based on the existing data, 630 heads of households are 67 families $(12 \%)$ belonging to preprosperous (very poor), and 10 families are prosperous I (poor). As the following table

\section{B. Implementation Model of Community Empowerment of Poor Fishermen}

\section{Organizational and Inter-organizational Implementation Analysis}

One of the factors that influence the success of the poor fishermen empowerment program is the behavior of organizational and inter-organizational implementation, which includes two components namely; commitment and coordination.

The commitment here is a mutual agreement with the relevant agencies in maintaining the stability of the organization and network among the existing institutions. Various programs in poverty alleviation efforts in fishing communities have been done by both government and other related parties. One of the programs developed so far is the Coastal Economy Community Empowerment Program (PEMP), which has so far not been fully implemented. Similarly, other programs, such as the Desa Mandiri (Independent Village) program, do not seem to be consistent with what has been planned in the planning stage of the program, or the vision with reality. Many factors cause such distortions, for example because programs born are not / have not been fully supported by agencies. This is where the agency's commitment is needed not to prioritize the interests of each in achieving the program objectives that have been set. it is clear that without any commitment in cooperation, it is impossible that the implementation of the poor fishermen community empowerment program can run properly. Therefore, there must be a commitment to organizations and inter-organization implementing empowerment programs that are marked by a Memorandum of Understanding (MoU) in running the fishing community program, so that social problems in the islands can be resolved quickly.
The coordination is a form of activity carried out by a cross-sectoral organization as the implementer of the program is bound within the network of local economic growth. This is one of the most urgent factors in inter-organizational networks and influences the determination of regional economic growth strategies.[9][10][11]. Coordination is conducted with crosssectoral organizations as implementation of community empowerment programs bound by fishermen in the network of regional economic growth. Coordination is carried out, both in terms of decision-making, especially in the provision of data and information are in terms of implementation activities. It is considered important, because in Mattiro Bombang Village has a kind of potential economic resources. Stakeholders are expected to coordinate data, such as regional potentials, investment activities, business opportunities, and market opportunities. However, it has not been realized, because it is not used to doing such activities. Organizations such as secretarial teams are not or have not been patterned as pattern systems in business organizations. In decision-making, the "top-down" model is still widely used, in which power becomes an orientation in that regards. The above phenomenon shows that the coordination system has not been working as expected. Besides not yet effective to provide accurate information to its stakeholders, also has not effectively run its strategy. The absence of victory to actualizing those methods clinched alongside territorial monetary development may be basically because of the inadequate coordination, both from those procurements of data on the possibility of claiming territorial monetary assets Previously, a coordinated manner, and also those usages of the nearby financial development system.

2. Down Level Behavior Analysis (Street Level Bureaucracy)

Lower-level bureaucratic behavior in the poor fishermen community empowerment program is largely determined by village-based organizations, in the form of lower-level bureaucracy (Street Level Bureaucracy) such as Village Community Organization or Lembaga Kemasyarakatan Desa (LKD), as the real program implementer [6][12]. This is in accordance with Ministry of Home Affairs Regulation No. 5 of 2007 and Government Regulation No. 72 of 2007. He is a partner of the Village Government and Village Leaders in empowering the community.

In addition, assist in the implementation of government affairs, controlling, utilizing, maintaining and developing development in a participatory manner. This is the reason why so the existence of LKD in the poor fishermen community empowerment program in Mattiro Bombang is good and can be called as a social node, because this becomes the most prominent change in society, program motivator, and excavator of ideas based on consensus [13].

Furthermore, the lower level of bureaucratic behavior that is meant here is the ability of LKD in running the programs that have been established. This LKD ability as an implementer is already a provision in this program and also shows as a socioeconomic empowerment program for fishermen communities. The ability of LKD in the socioeconomic empowerment program of society is shown by 
the discretion in carrying out its duties. It is just as the result of the interview indicates the determination of LKD in the village is determined completely by the Village Head, without going through the selection process. Such a process indicates the absence of transparency, taking place under a paternalistic, paternalistic village leadership style.

Based on the description given above, there is still no clear discretion played by LKD as a village-based organization, as the organizer of activities in the village. This is triggered by some reasons, firstly; the implements, especially the village head and LKD, do not yet understand the real purpose of the empowerment program to be implemented. Secondly, the technical activities seem to be difficult to implement due to unavailability of counterparts; third, the implementing organization is very bureaucratic. These three things do not allow discretion for the implementer. The absence of regional economic integrated resource potentials leads to the determination and implementation of biased local economic growth strategies. As a result, the team of implementing organizations of this program has difficulty in obtaining or facilitating investors. Similarly, the difficulty of creating a "market niche" for the region's flagship commodities in that area.

\section{Goal Group Behavior Analysis (Target Group)}

Target group is referred here as the community and families of poor fishermen who are in the village of Mattiro Bombang, Sub-district of Liukang Tupabbiring Utara, Pangkep regency. The existence of this target group is very important for coastal empowerment programs because the success or failure of the program is determined by them. The positive support of the community as a target group is very important to the success of the program.

Conversely, negative support or negative action will have a negative impact on this program in achieving its goals. This is related to the behavior of the community or the characteristics of the target group as one of the factors influencing the success of the empowerment program [4]. Thus, the implementation performance of the poor fishermen empowerment program is strongly influenced by the characteristics of participants, ie; support or reject [7]. In other words, the successful implementation of this program is determined by the support and conducive environment.

Thus, the success of policy implementation can be measured from the process of achieving the outcomes. The process of implementing the policy can only be achieved if it is in accordance with the rules[14]. Similarly, impacts or effects on the community either individually or in groups, if the policy can be understood or interpreted according to program objectives to be implemented.

\section{CONCLUSION}

Implementing organizations of poor fishermen community empowerment program in Mattiro Bombang Village, Liukang Tupabbiring Sub-District, regency in implementing the established program has not represented the results seriously determining and implementing strategies in the context of local economic growth in the program area. Such decision- making demonstrates the role of other members of the organization or the personnel belonging to the program implementing team only in favor of the decision, has no great opportunity in contributing to the birth of a decision or policy reflecting the common good.

The implementation of the program at the lower bureaucracy level that resembles the Village Community Institution is very difficult to do discretion because LKD is appointed by the head of the local village, not chosen by the community. Thus, the LKD is in the bureaucratic organization, so that every space in carrying out the work is always based on the 'guidance' of the head of the village. Such models demand loyality to the Village Head, and LKD is no longer oriented towards achieving goals that require innovation in the mind and in action.

The success or failure of poor fisherman community empowerment program in Mattiro Bombang, Sub-district Liukang Tupabbiring Utara is characterized by positive or negative support from the fishermen community as the target group. Community behavior or characteristics of the target group as one of the determining factors influences the success of the program, or the community is not interested in the program. In other words, the successful implementation of the fishermen community empowerment program is mainly determined by a conducive environment and support.

\section{REFERENCES}

[1] Kusnadi, 2002. Social Conflict of Fisheries on Poverty and Seizure of fishery resources (Konflik Sosial Nelayan Kemiskinan dan Perebutan Sumberdaya Perikanan).LkiS; Yogyakarta.

[2] Mubyarto; L. Soetrisno ; R.Dove, Fisheries and Poverty, Economy and Antropology Studies in two Desa Pantai (Nelayan dan Kemiskinan Studi Ekonomi Antropologi di Dua Desa Pantai). Rajawali: Jakarta. 1984

[3] Mubyarto and L. Soetrisno. Village Rural Development Study in Riau Province. Center for Rural and Regional Development (Studi Pengembangan Desa Pantai di Provinsi Riau). Center for Rural and Regional Development Universitas Gadjah Mada, Yogjakarta. 1988

[4] W. Soren C, Handbook of Public Administration, Edited by B.Guy Peters \& John Pierre. SAGE Publications. 2004

[5] J. Jr .O. Laurence. "Research on Policy Implementation Assesment and Prospects", Journal of Public Administration Research and Theory. 10: 2000 , pp. 263-88

[6] M. Lipsky. Street-Level Bureaucracy: The Dilemmasof the Individual in Public Services. New York: Russel Sage Foundation. 1980

[7] V. Meter, Donald S and V. Horn, E.Carl. "The Policy Implementation Process: A Conceptual Framework, Administration and Society". 6, 1975. pp. 445-68.

[8] K.Y.Robert, Case of Study (Studi Kasus). Jakarta. Raja Grafindo Persada. 2000

[9] B.Tjokroamidjojo. Introduction to Development Administration (Pengantar Administrasi Pembangunan). Jakarta: LP3ES, 1994

[10] Laurance. J. O'Toole Jr, 2000; Research on Policy Implementation Assesment and Prospects, Journal of Public Administration Research and Theory. 10: 263-88.

[11] Alwi, The Analysis of networking system between Organization in order to decides the strategy the Regional Economic Growth.(Analisis Tentang Sistem Jaringan Antar Organisasi Dalam Penentuan Strtaegi Pertumbuhan Ekonomi Daerah ( Studi Kasus Pada Badan Pengelola 
Kawasan Pengembangan Ekomomi Terpadu, Pare-Pare- Sulsel). Unpublished dissertation. Universitas Padjadjaran, Bandung. 2007

[12] R.Torenvlied, "Political Control of Implementation Agencies,Effects of Political Consensus on Agency Compliance".Rationality and Society. 8 (1), 1996. pp. 25-26

[13] A.Anwar. The Implemetation of national program for Community Empowerment (Implementasi Program Nasional Pemberdayaan Masyarakat, Studi Kasus Pengembangan Infrastruktur Sosial Ekonomi Wilayah Di Kabupaten Bone.) 2011

[14] M. S Grindle (Ed). Politics and Apolicy Implementation in the third world, New Jersey, Princetown University Press. 1980 